\title{
PERAN ULAMA NAHDLATUL ULAMA \\ DALAM MENYIARKAN PAHAM KEAGAMAAN MODERAT DI PROVINSI LAMPUNG
}

\author{
Moh. Bahrudin \\ UIN Raden Intan Lampung \\ moh.bahruddin@radenintan.ac.id
}

\begin{abstract}
Abstrak
Nahdlatul Ulama (NU) memiliki paham keagamaan yang tawasuth (moderat), tasamuh (tolerans), tawazun (seimbang) dan amar ma'ruf nahi munkar. Dengan doktrin yang demikian, NU senantiasa berpartisipasi aktif dalam proses pembangunan. Ulama NU Lampung memiliki peran yang sangat signifikan dalam menyebarkan paham keagamaan yang moderat di Lampung. Strategi yang ditempuh NU Lampung dalam menyiarkan paham keagamaan moderat adalah dengan membuat klasifikasi kelompok sasaran. Melalui jalur pendidikan formal dan non formal dengan sasaran utamanya adalah generasi muda. Melalui majelis-majelis thariqah yang sasaran utamanya adalah kelompok orang dewasatua. Melalui khutbah, ceramah, dan dakwah secara umum kepada seluruh lapisan masyarakat tanpa membedakan usia. Melalui jalur politik dengan sasaran para elit politik, birokrat dan para pelaku usaha. Melalui jalur lintas agama yang sasarannya adalah saudara sebangsa setanah air yang non muslim. Strategi yang demikian sangat efektif menyiarkan paham keagamaan yang moderat, terbukti bahwa NU Lampung mendapat julukan "Jawa Timurnya NU" di luar pulau Jawa.
\end{abstract}

Kata Kunci : Ulama, NU, Moderat, Lampung

\begin{abstract}
Nahdlatul Ulama (NU) along with its religious doctrines of tawāsut (moderate) tasāmuh (tolerant), tawāzun (balanced) and amar ma'ruf nahi munkar (commanding the good and forbidding the evil) continues to participate actively in the development process. The NU clergy in Lampung has played a very significant role in disseminating a moderate religious understanding in Lampung province. The strategy of disseminating the moderate religious ideology is by making a classification of the target groups. It mainly includes both formal and non-formal educations
\end{abstract}


for the younger generation, thariqah for adults-old group, as well as sermons, lectures, and propagation in general for all levels of society regardless of age. In addition, the classification has also been introduced through political channels targeting political elites, bureaucrats and business actors and through an interfaith dialogue for non-Muslim countrymen. In brief, the strategy is considered very effective in broadening the moderate religious understanding. Hence, NU of Lampung has proven itself as "The East Java NU" outside of Java.

Keywords: Ulama, NU, Moderate, Lampung

\section{A. Pendahuluan}

Al-Qur'an dan Sunah mengandung nilai-nilai normatif dan nilai-nilai etik yang memiliki fungsi sebagai petunjuk bagi manusia (hudan li al-nas) sehingga manusia terlepas dari jalan kegelapan menuju jalan terang benderang. Rasulullah Saw. menyatakan :

تركت فيكم شيئين لن تضلوا بعدهما كتاب الله و سنتى (رواه الحاكم ) .

Artinya: Aku tinggalkan untuk kamu sekalian dua hal yang kamu sekalian tidak akan tersesat setelah (berpegang) keduanya, yaitu Kitab Allah (al-Qur'an) dan Sunahku. (HR Al-Hakim).

Akan tetapi al-Qur'an dan Sunah tidak akan memiliki kebermaknaan tanpa pemahaman dan pengamalan yang benar oleh umatnya. Nilai-nilai normatif dan nilai-nilai etik yang terdapat di dalam al-Qur'an dan Sunah merupakan ide samawi yang memerlukan interpretasi, internalisasi, dan implementasi oleh umatnya untuk bisa landing dalam perikehidupan. Oleh karena itu, problem yang sangat mendasar untuk umat Islam adalah bagaimana proses interpretasi, internalisasi, dan implementasi pesan-pesan yang terkandung dalam al-Qur' an dan Sunah ke dalam realitas kehidupan.

Konsekuensi logis dari aktifitas interpretasi terhadap nash alQur'an dan Sunah, akan melahirkan paham keagamaan yang beragam di tengah masyarakat, di antaranya dikenal dengan paham keagamaan yang moderat. Moderat dalam beragama memiliki konotasi sikap yang tenang, seimbang, konsisten serta mengambil jalan tengah

${ }^{1}$ Jalal al-Din Abd al-Rahaman Al-Suyuthi, Al-Jami' al-Shaghir, Juz I (Indonesia: Dar Ihya' al-Kutub al-'Arabiyah, tt.), h. 130 
dalam semua urusan agama tanpa melebihkan atau mengurangkan. ${ }^{2}$ Al-Rhaghib al-Ashbahani membagi moderat menjadi dua yaitu moderat yang terpuji dan moderat tercela. Alhasil moderat dalam beragama adalah mengikuti ajaran beragama Islam yang sesuai (lurus) dan benar, dikuatkan oleh rasio, sesuai fitrah manusia serta nyata dalam kehidupan manusia ${ }^{3}$ Tindakan, ucapan, dan kata hati sejalan dengan ajaran yang bersumber pada al-Qur'an dan Hadis.

Salah satu elemen yang sangat penting dalam penyiaran dan pengamalan ajaran agama yang moderat adalah peran tokoh agama, orang yang memberikan bimbingan dan pendidikan keagamaan yang dikenal dengan ulama. Predikat ulama diperoleh melalui poses panjang dalam masyarakat secara informal dan setelah melalui penilaian objektif masyarakat, baik integritas moral, intelektual, keahlian, ibadah dan lain sebagainya. ${ }^{4}$ Memang peran ulama pada awalnya adalah memberikan pelayanan pendidikan untuk umat Islam. Namun dalam perkembangannya, ulama tidak semata-mata memberikan bimbingan dan pendidikan keagamaan semata, tetapi juga mencakup berbagi aspek kehidupan masyarakat di segala bidang.

Di antara kontribusi ulama pada dinamika pembangunan di Indonesia yakni peran ulama dari kalangan Nahdlatul Ulama (NU). Nahdlatul Ulama adalah organisasi yang berdiri pada tahun 1926, merupakan organisasi keagamaan dan kemasyarakatan (jam'iyah diniyah wal-ijtima'iyah) yang menfokuskan diri pada bidang dakwah, pendidikan dan sosial kemasyarakatan berdasarkan ajaran Islam menurut paham ahlussunnah wal jama'ah. Meski demikian, sebagai konsekuensi logis infrastruktur dan menjadi bagian tak terpisahkan dari keseluruhan bangsa Indonesia, NU selalu berperan aktif dalam membangun dan mengembangkan kultur politik yang dinamis dan islami dalam bingkai Negara Kesatuan Republik Indonesia. $^{5}$

${ }^{2}$ Muhammad Al-Zuhaili, Moderat dalam Islam, Cet. Ke-1, (Jakarta : Akbar Media Sarana, 2005), h. 193

${ }^{3}$ Muhammad Al-Zuhaili, Moderat dalam Islam, h. 194-195

${ }^{4}$ Ahmad Rifa'i Harahap dkk (ed), Ensiklopedi Praktis Kerukunan Umat Beragama, Cet. Ke-2, (Medan: Perdana Publishing, 2015), h. 578

${ }^{5}$ Sahal Mahfudh, Pidato Iftitah Rais 'Aam PBNU pada acara Musyawarah Nasional/Komferensi Besar NU, (Jakarta, tanggal 25 Juli 2002), h. 2 
Sesuai dengan Khittah Al-Nahdliyah 1926, NU memiliki spirit berupa sikap batin, cara pandang, cara berpikir, cara bertindak dan sikap sosial dan paham keagamaan yang: tawasuth dan i'tidal (moderat dan adil), tasamuh (tolerans), tawazun (seimbang) dan amar ma'ruf nahi munkar. ${ }^{6}$ Moderat dalam beragama dimaksudkan sebagai tengah-tengah, seimbang, istiqamah, adil, mudah dan mengambil bagian jalan tengah. Dengan paradigma dan doktrin yang demikian, NU senantiasa berpartisipasi dalam membangun dan mengembangkan masyarakat Indonesia yang bertakwa kepada Allah SWT., cerdas, berakhlak mulia, terampil, adil, tenteram dan sejahtera. Berpijak pada platform organisasi yang demikian pula, kini NU menjadi organisasi keagamaan terbesar di Indonesia.

Provinsi Lampung merupakan jalur pintu gerbang migrasi penduduk yang berasal dari pulau Jawa ke pulau Sumatera atau sebaliknya, sehingga tidak sedikit masyarakat yang berawal hanya sekedar melintas, namun selanjutnya tinggal menetap dan menjadi salah satu bagian penduduk Lampung. Sai Bumi Rua Jurai menjadi slogan masyarakat adat Lampung, yang bermakna satu bumi didiami oleh dua kelompok masyarakat, yaitu masyarakat asli dan pendatang. Konsekuensi ini membawa perubahan corak agama terutama bagi kalangan masyarakat muslim di Lampung, yaitu semakin beragamnya budaya dan ajaran agama baik yang sudah menjadi rutinitas maupun yang belum menjadi rutinitas bagi kalangan muslim di Provinisi Lampung.

Data statistik menunjukkan di Provinsi Lampung terdapat 738 Pondok Pesantren dengan jumlah santri mencapai 54.722 orang dan 709 Madrasah Diniyah dengan jumlah ustad mencapai 2.971 siswa $^{7}$ yang hampir keseluruhannya dikelola oleh ulama NU. Data dan fakta tersebut telah menempatkan NU Lampung pada posisi 3 besar secara nasional dalam pengelolaan lembaga pendidikan di

${ }^{6}$ Rumadi, Andi Najmi Fuaidi, Mahbub Ma'afi (ed), Hasil-Hasil Muktamar Ke-33 Nahdlatul Ulama, Cet. Ke-1, (Jakata : Lajnah Ta'lif wan Nasyr PBNU, 2015), h. 97

7 Tim Penyusun Kementerian Agama Provinsi Lampung, Kementerian Agama Provinsi Lampung dalam Angka: Data Statistik Keagamaan Tahun 2014, (Bandar Lampung, Kementerian Agama Provinsi Lampung, 2015), h. 49-51 
lingkungan NU, sehingga muncul julukan NU Lampung sebagai "Jawa Timur" nya NU di luar pulau Jawa. ${ }^{8}$

Berdasakan hal tersebut, maka dapat terlihatlah bahwa perkembangan NU secara nasional tidak terlepas dari peran dan kiprah ulama NU Provinsi Lampung. Hanya saja, sampai saat ini belum ada data autentik dan kredibel tentang kiprah ulama NU di Lampung dalam menyebarkan paham keagamaan moderat yang dapat dipertanggungjawabkan secara ilmiah. Apalagi dengan maraknya isu bahwa paham radikal ISIS (Islamic State of Irak and Syiria) telah banyak mempengaruhi sebagian rakyat Indonesia, sehingga mengungkap dan menyegarkan kembali penyebaran paham keagamaan yang moderat menjadi sangat signifikan dan urgen. Oleh karena itu tulisan ini bermaksud melacak dan mendeskripsikan kiprah dan peran ulama NU di Provinsi Lampung, dengan titik fokus kajian meliputi: visi, misi dan karakteristik paham keagamaan yang dikembangkan oleh NU Provinsi Lampung, dan strategi yang ditempuh oleh NU Provinsi Lampung dalam menyebarkan paham keagamaan moderat di Lampung.

Data-data kualitatif yang dikumpulkan digunakan untuk mendeskripsikan interaksi ulama NU secara kultural mapun struktural dalam penyiaran paham keagamaan yang moderat di provinsi Lampung. Analisis historis digunakan untuk mengetahui konfigurasi yang jelas mengenai peran, partisipasi dan kontribusi ulama NU terhadap dinamika perkembangan masyarakat Lampung, khususnya mengenai paham keagamaan yang dianutnya.

\section{B. Paham Keagamaan Moderat dalam Islam}

Sesungguhnya metode Islam dalam kemoderatan dan keseimbangan adalah metode pertengahan yang telah disyariatkan oleh Allah SWT. Budhy Munawar-Rachman menjelaskan bahwa alQur'an juga menganut prinsip adanya realitas tentang pluralitas agama (QS. 2 : 62), kebebasan beragama (QS. 2: 256), hidup berdampingan secara damai (QS. 109: 1-6), bersikap positif dalam berhubungan dan bekerjasama dengan umat lain yang tidak seagama (QS. 60 : 8), mengharuskan umat Islam bersikap dan bertindak adil

\footnotetext{
${ }^{8}$ Khairuddin Tahmid, Wawancara Pribadi, 12 Agustus 2017.
} 
terhadap umat non-muslim (QS. 60:80) dan untuk melindungi tempat-tempat ibadah semua agama (QS. $22: 40){ }^{9}$

Said Agil Husin al-Munawar berpendapat bahwa dalam mewujudkan kemaslahatan, agama telah menggariskan dua pola dasar hubungan yang harus dilaksanakan oleh pemeluknya, yaitu hubungan secara vertikal dan hubungan secara horizontal.

1. Hubungan vertikal, yaitu hubungan antara pribadi dengan Khaliknya yang direalisasikan dalam bentuk ibadat sebagaimana yang telah digariskan oleh setiap agama. Hubungan tersebut dilaksanakan secara individual, tetapi sangat diutamakan untuk dilaksanakan secara kolektif atau berjama'ah. Pada hubungan vertikal ini berlaku toleransi agama yang hanya terbatas dalam lingkungan atau intern suatu agama.

2. Hubungan horizontal, yaitu hubungan antara manusia dengan sesamanya. Pada hubungan horizontal tidak hanya terbatas pada lingkungan suatu agama saja, melainkan berlaku kepada orang yang tidak seagama, terutama dalam bentuk kerjasama dalam masalah-masalah yang berhubungan dengan kemasyarakatan atau kemaslahatan umum. Dalam hal seperti inilah keberlakuan toleransi antar umat beragama. Perwujudan toleransi seperti ini walaupun tidak berbentuk ibadat, namun bernilai ibadat, karena kecuali melaksanakan suruhan agamanya, juga bila pergaulan antar umat beragama berlangsung dengan baik, berarti tiap umat beragama telah memelihara keberadaan agama masing-masing. ${ }^{10}$

Selanjunya syari'at Islam telah menyusun pondasi yang kuat dan dasar yang baik serta hukum yang dapat menjadi petunjuk dalam segala bidang, antara lain:

\section{Moderat Dalam Berkeyakinan}

Islam diturunkan dengan seimbang, adil dan tengah-tengah antara agama-agama yang lain (umatan wasathan). Umat yang berpijak pada keadilan dan keseimbangan tidak akan memihak dan condong pada salah satu pihak dengan mengabaikan yang lain. Setiap

${ }^{9}$ Budhy Munawar-Rachman, Argumen Islam untuk Pluralisme, (Jakarta: Grasindo, 2010), h. 20

${ }^{10}$ Said Agil Husin Al-Munawar, Fikih Hubungan Antar Agama, Cet. Ke-3, (Jakarta: Ciputat Press, 2005), h. 14 
umat Islam meyakini, mempercayai, membenarkan dan memuliakan seluruh Nabi dan Rasul. Meskipun para nabi tersebut tidak mempunyai pengikut, dan yang ditinggalkan hanya sunahnya, namun umat Islam mau menjadikan dan mempercayai ajara tersebut sebagai bagian sumber hukum dan pedoman agama.

Elemen penguat kemoderatan dan keseimbangan dalam Islam adalah mempermudah dalam menjalankan kewajiban, yaitu sekuat atau semampunya (mastatho'na) berdasarkan firman Allah SWT yang terdapat dalam surat al-Baqarah ayat 185 :

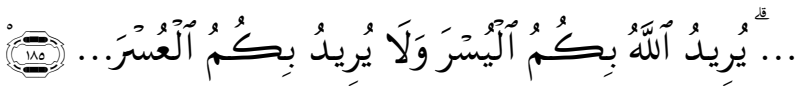

“... Allah menghendaki kemudahan bagimu, dan tidak menghendaki kesukaran bagimu... (QS. al-Baqarah: 185).

Ayat tersebut juga diperkuat dengan sabda Nabi yaitu:

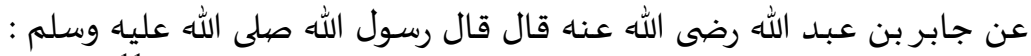

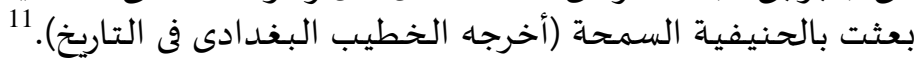

(Diriwayatkan) dari Jabir bin Abdillah, ia berkata: Rasulullah saw. Bersabda: Aku diutus untuk membawa agama yang benar lagi tolerans. (HR Al-Khathib al-Baghdadi dalam kitab AlTarikh).

\section{Terbukanya Pintu Rukhsah}

Kesempatan mencakup segala aspek, baik ibadah, akidah, muamalat dan perilaku sehari-hari. Sehingga hal ini tidak memberatkan bagi umat Islam dalam menjalankan peraturan dan larangan dari Allah SWT. Dalam hadis yang diriwayatkan oleh Baihaqi disebutkan:

عن إبن عمر رضى الله عنه قال قال رسول الله صلى الله عليه وسلهم إن الله

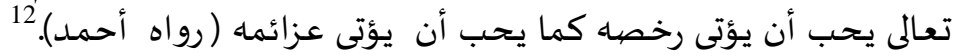

(Diriwayatkan) dari Ibnu Umar RA, ia berkata, Rasulullah Saw. bersabda: Sesungguhnya Allah Ta'ala senang untuk

${ }^{11}$ Jalal al-Din Abd al-Rahaman Al-Suyuthi, Al-Jami' al-Shaghir, h. 126

${ }^{12}$ Muhammad bin Isma'il Al-Shan'ani, Subul al-Salam, Juz I, (Bandung: Dahlan, tt.), h. 38 
memberikan berbagai hukum keringanan, sebagaimana Allah juga senang untuk memberikan hukum asalnya. (HR. Ahmad).

Hikmah dari rukshah ini adalah kemudahan, dihilangkanya kesempitan dan memberikan keringanan dalam menjalankan ibadah, serta tidak benci terhadap ajaran syariat dan ibadah. ${ }^{13}$

\section{Konsisten Dalam Menjalanknya Walaupun Hanya Sedikit}

Kemampuan menakar kekuatan dalam menjalankan ibadah adalah hal penting, sehingga dalam menjalankan ibadah bisa rutin dan berkesinambungan (mudawamah). Islam lebih mengutamakan amalan yag sedikit tetapi dilaksanakan dengan cara yang terus-menerus, dibandingkan dengan amalan yang banyak tetapi hanya diamalkan sesekali saja. Perintah ini sesuai dengan sabda Nabi Saw. yang diriwayatkan dari Abi Hurairah:"Ambillah amalan yang sesuai dengan kemapuan kalian, karena sesungguhnya Allah tidak memutus pahala, sampai kalian sendiri yang bosan. Sesungguhnya agama yang lebih disukai Allah adalah amal yang dikerjakan terusmenerus".

\section{Moderat Dalam Perilaku}

Perilaku masyarakat maupun adat istiadat dalam ruang lingkup keluarga dan kondisi pribadi perlu disesuaikan dengan agama yang meliputi beberapa aspek, antara lain moderat dalam pakaian, moderat dalam makan dan minum, moderat dalam adat kebiasaan, moderat dalam dalam mengendalikan emosi, moderat dalam mahar dan moderat dalam membelanjakan harta sesuai dengan firman Allah Swt. dalam surat al-Furqan : 67, yaitu:

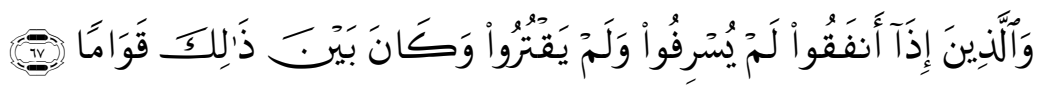

Dan orang-orang yang apabila membelanjakan (harta), mereka tidak berlebihan, dan tidak (pula) kikir, dan adalah (pembelanjaan itu) di tengah-tengah antara yang demikian. (QS. Al-Furqan: 67).

${ }^{13}$ Abu Ishaq Al-Syathibi, al-Muwafaqat, II, (Mesir: Mushthafa al-Babi alHalabi, 1976), h. 86 dan 96 


\section{Moderat dalam Menjalankan Peraturan}

Moderat dan seimbang dalam perilaku dan berinteraksi itu adalah sebuah metode dalam Islam yang secara umum dari tiap cabang, bagian dan hukum-hukumnya. Tidak satupun hukum fikih kecuali telah dianjurkan moderat dan seimbang di setiap bidangnya. Di dalam menjalankan peraturan Islam mengajarkan kepada pemeluknya untuk menaati dengan lillahi ta'ala selama perintah tersebut tidak bertentangan dengan perintah Allah SWT. Seperti bagaimana sikap seorang anak kepada kedua orangtua, bagaimana sikap seorang musim bergaul di lingkungan masyarakat dan lainlain. ${ }^{14}$

Pemahaman akan Islam moderat merupakan bagian dari pribumisasi Islam Nusantara. Pemahaman ini akan membawa umat Islam keluar dari sifat eklusifisme menjadi inklusifisme. Pemahaman akan Islam moderat sejalan dengan pendapat William Lidlle yang menggolongkan pemahaman kedalam aliran substansialis. Aliran ini berkeyakinan bahwa pesan yang disampaikan dalam al-Qur'an dan Hadis yang bersifat abadi dalam esensinya dan universal dalam maknanya. Pesan dalam al-Qur'an dan Hadis harus ditafsirkan kembali oleh generasi kaum muslim yang sesuai dengan kondisi sosial yang berlaku pada masanya.

Pada masa perjalanannya, kondisi persoalan ideologi yang terjadi di Indonesia pada masa Orde Baru menerapkan kebijakan atas asas tunggal Pancasila bagi semua organisasi masyarakat (ormas). Beragam reaksi muncul dari kaum muslim, baik reaksi terhadap pemerintah maupun sesama ormas Islam sendiri seperti Himpunan Mahasiswa Islam (HMI) ditanah Jawa menjadi HMI Diponegoro yang pro Pancasila dan HMI yang menolak Pancasila. Selain itu juga, Pelajar Islam Indonesia (PII) terpaksa dibubarkan karena menolak asas Pancasila. ${ }^{15}$

Kondisi ini mengharuskan bagi ormas Islam untuk menerima asa tunggal Pancasila ini, secara berangsur-angsur organisasi Islam

\footnotetext{
${ }^{14}$ Muhammad Al-Zuhaili, Moderat dalam Islam, Cet. Ke-1, (Jakarta : Akbar Media Sarana, 2005), h. 212-228

${ }^{15}$ M. Rusli Karim, Negara dan Peminggiran Islam Politik, (Yogyakarta: Tiara Wacana, 1992), h. 127
} 
menyesuaikan diri seperti NU pada Musyawarah Nasional di Situbondo pada tahun 1983 dan Muktamar Surabaya Tahun 1984 menyatakan menerima Pancasila sebagai asas kehidupan sosial dan politik serta asas organisasi NU. Tahun 1985 disusul organisasi Muhamadiyah pada Muktamar ke 41 Tahun 1985 di Surakarta. ${ }^{16}$

Polemik mengenai asas Pancasila, yang kemudian memunculkan pemikiran yang moderat di sejumlah kalangan, seperti Wakil Rais 'Am NU pada Tahun 1980an mengungkapkan bahwa perbedaan kondisi geografis antara Indonesia dan Timur Tengah ini untuk meyakinkan mahasiswa HMI untuk meminta NU tidak menyetujui asas Pancasila. Ini pertama seorang ulama menciptakan pandangan yang merujukkan antara Pancasila dan Islam dalam rangka menghentikan konflik ideologis yang berkepanjangan. ${ }^{17}$ Selain itu Kiai Achmad menganjurkan sikap berada ditengah-tengah (attawassuth), sikap adil (al-i'tidal) dan seimbang (at-tawwaazun) yang menjadi panutan dan menjadi tindakan yang baik dalam kehidupan sehari-hari. ${ }^{18}$ Sikap moderat dari kalangan Islam itulah yang kemudian mampu berbicara di penghujung pemerintahan Presiden Soeharto.

Menurut Mitsuo Nakamura dan Robbet W. Hefner bahwa kecurigaan pemerintah terhadap ideologis umat Islam hilang setelah Pancasila diterima menjadi satu-satunya asas bagi organisasi politik dan masyarakat, membuat umat Islam dapat berkembang secara lebih sehat dan dapat menjadi tuan rumah di negeri sendiri. ${ }^{19}$

Aliran moderat juga memasuki dunia birokrasi dan teknokrasi kemudian berupaya mendekatkan pemerintah dengan Islam yang sebelumnya terkesan renggang, khususnya pasca Masyumi yang mendapat citra memperjuangkan ideologi negara Islam pada Sidang

${ }^{16}$ Abdul Munir Mulkhan, Perubahan Perilaku dan Polarisasi Ummat Islam 1965-1987, (Jakarta: Rajawali Press, 1989), h. 127

${ }^{17}$ Andree Fierlard, NU Vis A Vis Negara: Pencarian Isi, Bentuk, dan Makna, (Yogyakarta: LkiS, 1992), h. 252

${ }^{18}$ HM. Amin Haedari, Masa Depan Pesantren, (Jakarta : IRD Press, 2004), h. 24

${ }^{19}$ Saiful Mujanni, Kultur Kelas Menengah Muslim da Kelahiran ICMI: Tanggapan terhadap Robert W Hefener dan Mitsuo Nakamura, dalam Nasrulloh Ali Fauzid (Ed), ICMI : Antara Status Quo dan Demokrasi, (Bandung: Mizan, 1995), h. 79 
Konstituante pada Tahun 1957-1958. Padahal dilain pihak kekuatan masyarakat di daerah-daerah pada Pemilu 1955 memenangkan Masyumi saat itu sebagian besar pada waktu itu sebenarnya adalah pendukung Golkar. Generasi muda muslim santri yang pada umumnya adalah alumni HMI, ikut menjadi bagian penting, baik dari elite politik dan pemerintahan di daerah-daerah maupun center of excellence. $^{20}$

Perjalanan yang dilakukan aliran Islam moderat ini mulai berhasil dengan terlaksananya proses Islamisasi birokrasi dan Golkar. Padahal Golkar dan ABRI pada saat itu digambarkan sebagai anti Islam dengan peristiwa-peristiwa seperti kerusuhan Tanjung Priok, Lampung, GPK Aceh. Termasuk sikap umat Islam terhadap peranan tokoh Ali Moertopo dan Benny Moerdani sebagai orang yang bermain dalam citra itu. Namun di lingkungan birokrasi saat itu, sebenarnya sedang berlangsung proses santrinisasi aliran abangan. Menurut Dr. Anwar Haryono, bahwa santri abangan dalam masyarakat Islam bukan sebuah dikotomi, melainkan soal perbedaan gradual saja. Karena itu sesungguhnya terjadi lebih tepat disebut sebagai santrinisasi kaum muslim abangan daripada islamisasi orangorang non-muslim. Itulah makna "Islamisasi birokrasi" yakni sebuah integrasi kultural antara santri dan abangan, di mana keduanya merupakan varian budaya dari pemeluk agama yang sama. ${ }^{21}$

Pada dasawarsa 70-an merupakan masa "panen sarjana" pertama bagi kaum muslimin berupa lulusnya putra dan putri mereka dari perguruan tinggi. Pada dasawarsa 90-an mereka bekerja di lingkungan birokrasi secara natural dengan sendirinya telah menduduki posisi penting. Pada gilirannya berperan penting dalam melakukan hubungan pemerintah dengan kaum muslimin, disamping mempercepat dan mendorong proses santrinisasi dikalangan birokrat sebagai konsekuensi logis dari tuntutan untuk mewujudkan "ketaqwaaan kepada Tuhan Yang Maha Esa sebagai bagian sumpah bagi pegawai negeri sipil dan ABRI. Proses ini menjadikan

${ }^{20}$ M. Dawwam Raharjo, Visi dan Misi Kehadiran ICMI: Sebuah Pengantar, dalam Nasrulloh Ali-Fauzid (Ed), ICMI : Antara Status Quo dan Demokrasi, (Bandung: Mizan, 1995), h. 34

${ }^{21}$ M. Dawwam Raharjo, Visi dan Misi Kehadiran ICMI: Sebuah Pengantar, h. 34 
persamaan sikap dan dan pandangan antara negara dan kelas menengah muslim serta kaum muslimin yang menimbulkan pergeseran politik yang besar dalam dasawarsa terakhir masa orde baru. ${ }^{22}$

Seiring dengan perubahan peta politik di Indonesia, gerakan Islam moderat juga mengalami perubahan. Seiring dengan berakhirnya masa orde baru, muncul fenomena menarik degan maraknya ormas Islam yang berhaluan radikal, militan dan fundamentalis. Ormas Islam semakin menunjukan momentumnya untuk melakukan gerakan memperjuangkan aspirasi Islam dengan munculnya beberapa ormas berhaluan radikal. ${ }^{23}$

Salah satu contoh untuk menanggulangi radikalisme, menurut KH Hasyim Muzadi perlu penanggulangan lebih serius dari kaum agama, dalam hal ini Islam moderat. Untuk menyebarkan pahampaham moderatisme, diperlukan peran aktif lembaga pendidikan Islam seperti madrasah, pesantren dan semacamnya. Moderat dalam beragama memiliki konotasi sikap yang tenang, seimbang, konsisten serta mengambil jalan tengah dalam semua urusan agama tanpa melebihkan, mengurangkan atau mengabaikan. ${ }^{24}$

\section{Sejarah Dan Kiprah NU Lampung}

\section{Kondisi Demografis Lampung}

Lampung merupakan Provinsi yang penduduknya terkenal sangat menjunjung tinggi adat-istiadatnya, dan sebagaimana masyarakat Indonesia pada umumnya sebelum Islam masuk ke Lampung, sebagian masyarakatnya diperkirakan banyak dipengaruhi dan atau menganut agama Hindu-Budha. ${ }^{25}$ Setelah pengaruh HinduBudha berakhir pada abad ke-15 M, maka masuk dan berkembanglah agama Islam di Lampung. Dewasa ini umat Islam merupakan penganut agama mayoritas di provinsi Lampung ini. Jumlah

${ }^{22}$ Bambang Pranowo, Islam Faktual : Antara Tradisi dan Relasi Kuasa, (Yogyakarta: Adicita Karya Nusa,1999), h. 106

${ }^{23}$ HM. Amin Haedari, Masa Depan Pesantren, h. 24

${ }^{24}$ Muhammad Al-Zuhaili, Moderat dalam Islam, h. 193

25 Kantor Wilayah Departemen Pendidikan dan Kebudayaan Propinsi Lampung, Sejarah Daerah Lampung, (Bandar Lampung : Bagian Proyek Pengkajian dan Pembinaan Nilai-Nilai Budaya Lampung, 1997), h. 1 
penduduk Lampung menurut agama yang dianut pada tahun 20016 dapat dilihat pada tabel berikut:

\section{Tabel 1}

Jumlah Penduduk Lampung Menurut Agama yang Dianut Tahun 2016

\begin{tabular}{c|l|r}
\hline No & \multicolumn{1}{|c|}{ Agama } & \multicolumn{1}{c}{ Jumlah } \\
\hline 1 & Islam & 7.377 .476 \\
\hline 2 & Kristen & 166.816 \\
\hline 3 & Katolik & 138.388 \\
\hline 4 & Hindu & 998.908 \\
\hline 5 & Budha & 135.096 \\
\hline & Jumlah & 8.816 .684 \\
\hline
\end{tabular}

Sumber: Kanwil Kementerian Agama Provinsi Lampung: Data Statistik Keagamaan Tahun $2016 .^{26}$

Sebelum NU menjelma secara organisatoris, pada tahap awalnya masuknya NU di Lampung melalui akulturasi sosial keagamaan dan kebudayaan yang dibawa oleh para pedagangpendakwah dari luar Lampung. Sebagai sebuah organisasi kemasyarakatan yang secara umur sudah cukup matang, NU Provinsi Lampung saat ini telah berkembang menjadi suatu organisasi keagamaan di daerah yang memiliki kharisma religius dan masih cukup disegani baik itu oleh Pemerintah Daerah maupun organisasi keagamaan dan kemasyarakatan lain yang ada di wilayah ini.

Keberadaan NU di Provinsi Lampung tidak terlepas dari sejarah keberadaan Lampung. Pada tahun 1964 Lampung menjadi propinsi memisahkan diri dari Sumatera Selatan. Pengurus Besar Nahdlatul Ulama (PBNU) membentuk mandataris menyusun pengurus NU Wilayah Lampung yang diketuai oleh K.H. Muhammad Zuhri. ${ }^{27}$ Pada saat berdirinya NU wilayah Lampung pada tahun 1964 terdiri dari tujuh cabang, yaitu: Cabang Teluk Betung, Kota Bumi, Menggala, Krui, Sukarame, Kota Agung dan Talang Padang. Kepengurusan NU wilayah Lampung sejak tahun 1964 sampai

${ }^{26}$ BPS Provinsi Lampung, Provinsi Lampung dalam Angka 2017, (Bandar Lampung, Cv. Jaya Wijaya, 2017), h. 106

${ }^{27}$ PWNU Propinsi Lampung, Sepintas Sejarah NU Lampung, (Lampung, 2014), h. 3 
sekarang yaitu: Periode 1964-1968 diketuai oleh H. M. Marhasen, S.S., Periode 1968-1979 diketuai oleh KH. Zahri, Periode 1979-1983 diketuai oleh H. Velta Jeli Panglima, Periode 1983-1992 diketuai oleh Drs. H. Romos Jaya Saputra, Periode 1992-1997 diketuai oleh KH. Khusnan Mustafa Ghufron, Periode 1997-2002 diketuai oleh KH. Khusnan Mustafa Ghufron, Periode 2002-2007 diketuai oleh Drs. KH. Khairuddin Tahmid, M.H., Periode 2007-2012 diketuai oleh KH. Ngaliman Marzuki, ${ }^{28}$ dan Periode 2012-2017 diketuai oleh KH. Soleh Bajuri, M.H.I.

\section{Visi dan Misi NU Lampung}

Dalam Anggaran Dasar dan Anggaran Rumah Tangga NU Pasal 5, disebutkan bahwa tujuan NU adalah memberlakukan ajaran Islam yang sesuai dengan paham Ahli Sunnah wal-Jamaah dan menganut salah satu mazhab yang empat di tengah-tengah kehidupan masyarakat di dalam wadah Negara Kesatuan Republik Indonesia. ${ }^{29}$ Untuk mewujudkan tujuan AD-ART tersebut maka NU melaksanakan usaha-usaha yaitu:

a. Pada bidang agama berupaya melaksanakan ajaran Islam menurut paham Ahli Sunnah wal-Jamaah dalam masyarakat dengan cara dakwah islamiah dan amar makruf nahi mungkar serta menumbuhkan ukhuwah islamiah.

b. Pada bidang pendidikan pengajaran dan kebudayaan berupaya terwujudnya penyelengaraan pendidikan dan pengajaran serta mengembangkan kebudayaan yang sesuai dengan ajaran Islam untuk membina manusia muslim yang takwa, berbudi luhur, terampil, berpengetahuan luas dan berguna bagi agama, bangsa dan negara.

c. Pada bidang sosial berupaya terwujudnya kesejahteraan rakyat dan bantuan terhadap umat manusia yang membutuhkan seperti anak yatim, orang fakir-miskin, serta masyarakat yang berkekurangan lainnya.

d. Di bidang ekonomi mengusahakan terwujudnya pembangunan ekonomi dengan mengupayakan pemerataan kesempatan untuk berusaha dan menikmati hasil-hasil pembangunan dengan

\footnotetext{
${ }^{28}$ Ibid.

${ }^{29}$ Anggaran Dasar dan Anggaran Rumah Tangga NU, BAB II Pasal 5
} 
mengutamakan tumbuh dan berkembangnya ekonomi kerakyatan.

e. Mengembangkan usaha-usaha lain yang beranfaat bagi masyarakat banyak guna terwujudnya khaira ummah.

Berdasarkan analisis terhadap kondisi objektif NU Provinsi Lampung saat ini, maka Visi atau kondisi ideal yang diharapkan oleh PWNU Lampung Masa Khidmah 2012- 2017 adalah: "Terciptanya NU Provinsi Lampung sebagai Organisasi yang Terkonsolidasi, Mantap dan Mandiri dalam Meningkatkan Pelayanan terhadap HakHak Jama'ah secara Demokratis \& Ber-Akhlaqul Karimah".

Adapun misi yang akan dijalankan oleh PW NU Lampung untuk mewujudkan visinya adalah sebagai berikut:

a. Penataan dan Pengembangan Manajemen Organisasi Oleh karenanya, kebutuhan akan sistem pengelolaan dan manajemen organisasi NU Lampung yang lebih efektif dan efisien tidak bisa ditunda-tinda lagi. Penataan organisasi dimulai dengan penataan sistem dan kemudian dilanjutkan dengan pengisian personel yang kompeten untuk menjalankan sistem tersebut.

b. Pengembangan Keagamaan; Bahwa perkembangan isu-isu keagamaan di Indonesia akhir-akhir ini membutuhkan sebuah sikap dan langkah yang cukup tegas. Munculnya radikalisme Islam dan gerakan-gerakan teror yang mengatasnamakan jihad merupakan sedikit dari fenomena tersebut. Kelompokkelompok yang mengatasnamakan Islam, berusaha hendak menegakkan Khilafah Islamiyah di Indonesia menggantikan Pancasila. NU sebagai sebuah kekuatan Islam yang lahir dan besar dengan ciri plurarisme jelas harus berdiri di barisan terdepan untuk mengembalikan Islam yang rahmatan lil alamin di Indonesia.

c. Pengembangan dan Peningkatan Pelayanan Jama'ah; Bahwa salah satu unsur terpenting dalam membesarkan NU Lampung adalah nahdliyin. Kesetiaan, pengabdian, dukungan moril yang telah diberikan oleh nahdliyin menuntut NU Lampung memberikan perhatian terhadap jama'ah-nya, yang sebagian besar dari kalangan menengah ke bawah. Usaha peningkatan kesejahteraan di bidang pendidikan, kesehatan, dan 
pemberdayaan ekonomi adalah sektor yang perlu digarap oleh NU Lampung.

d. Pengembangan Jejaring Kerjasama Kelembagaan; Potensi NU yang besar harus dimanfaatkan tidak saja untuk dukungan politik, tapi juga secara riil untuk pelaksanaan programprogram pemerintah dan instansi lainnya. Untuk itulah, Pemerintah dan beberapa lembaga internasional telah menjalin kerjasama program dengan $\mathrm{NU}$, termasuk didalamnya $\mathrm{NU}$ Lampung. Menjalin kemitraan sangat diperlukan agar programprogram NU dapat berjalan dengan baik dan memberikan manfaat yang besar bagi NU.

\section{Karakteristik Paham Keagamaan NU}

Nahdlatul Ulama mendasarkan paham keagamaannya kepada al-Qur'an, Sunah, Ijmak dan Qiyas dengan menggunakan pendekatan bermazhab. Secara akidah, mengikuti Imam Abu al-Hasan al-Asy'ari dan Imam Manshur al-Maturidi dan secara fikih mengikuti salah satu dari mazhab empat (Imam Abu Hanifah, Imam Malik bin Anas, Imam al-Syafi'i dan Imam Ahmad bin Hanbal). Pada bidang tasawuf, mengikuti anara lain Imam al-Junaidi al-Baghdadi dan Imam alGhazali.

Dalam kehidupan bermasyarakat, berbagsa dan beregara, Muktamar Ke-33 Nahdlatul Ulama di Jombang - Jawa Timur menegaskan bahwa sikap kemasyarakatan NU yang ingin ditegakkan dan ditumbuh kembangkan adalah :

a. Sikap tawasuth dan i'tidal; yakni sikap moderat (tengahtengah) yang berintikan kepada prinsip-prinsip hidup yang menjunjung tinggi keharusan berlaku adil dan lurus di tengahtengah kehidupan bersama. Dengan sikap dasar yang demikian NU akan selalu menjadi kelompok panutan yang bersikap dan bertindak lurus dan selalu bersifat membangun serta menghindari segala bentuk pendekatan yang bersifat ekstrem.

b. Sikap tasamuh; yakni sikap tolerans terhadap perbedaan pandangan baik dalam masalah keagamaan, terutama hal-hal yang bersifat furu'iyah atau menjadi masalah khilafiyah, serta dalam masalah kemasyarakatan dan kebudayaan.

c. Sikap tawazun, yakni sikap seimbang (harmoni) dalam berkhidmah. Menyertakan khidmah kepada Allah swt., 
khidmah kepada sesama manusia serta kepada lingkungan hidupnya, menyelaraskan kepentingan masa lalu, masa kini dan masa mendatang.

d. Amar ma'ruf nahi munkar, yakni selalu memiliki kepekaan untuk mendorong perbuatan yang baik, bermanfaat bagi kehidupan bersama, serta menolak dan mencegah semua hal yang dapat menjerumuskan dan merendahkan nilai-nilai kehidupan. ${ }^{30}$

Nahdlatul Ulama juga memandang pluralitas sebagai sebuah keniscayaan (sunnatullah), memberikan jaminan dan toleransinya dalam memelihara hubungan bersama dengan meletakkan nilai-nilai universal, seperti prinsip keadilan, kebersamaan dan kejujuran. Selanjutnya NU meletakkan konsep tata-kelola hubungan antar manusia dengan tiga bentuk ukhuwah yaitu: (1) ukhuwah islamiyah, persaudaraan sesama muslim yang tumbuh dan berkembang karena persamaan akidah/keimananan, baik di tingkat nasional maupun internasional; (2) ukhuwah wathaniyah, yang menyangkut hubungan kemasyarakatan, kebangsaan, dan kenegaran) di mana mereka sebagai sesama warga negara memiliki kesamaan derajat dan tanggung jawab untuk mengupayakan kesejahteraan dalam kehidupan bersama; (3) ukhuwah basyariyah, yang berkaitan dengan kesamaan martabat kemanusiaan untuk mencapai kehidupan yang sejahtera, adil dan damai.

Oleh karena itu NU memiliki kewajiban moral untuk membumikan paham keagamaan yang moderat di Nusantara ini dalam rangka mewujudkan Islam yang rahmatan lil 'alamiin. Di samping itu, NU menjunjung tinggi nilai-nilai keadilan (al-'adalah), kejujuran (al-shiddiq), persamaan (almusawah), kemandirian dan kesahajaan (qona'ah). Demikian pula halnya, profesionalitas, kebangsaan, kemanusiaan, demokratis dan amanah, juga diharapkan menjadi dasar tatanan kaidah sosial yang menopang prilaku sosial yakni kesemestaan, keteraturan, keselarasan dan ketenteraman.

\footnotetext{
${ }^{30}$ Rumadi, Andi Najmi Fuaidi, Mahbub Ma'afi (ed), Hasil-Hasil Muktamar Ke-33 Nahdlatul Ulama, h. 97
} 


\section{Strategi Penyiaran Paham Keagamaan NU Lampung}

Secara garis besar terdapat beberapa strategi yang ditempuh oleh NU Lampung dalam menyiarkan paham keagamaan moderat, di antaranya ialah :

a. Melalui jalur pendidikan dengan sasaran utamanya adalah generasi muda, baik pendidikan yang sifatnya formal maupun non formal, yang secara teknis dikoordinasikan oleh perangkat organisasi yang bernama Lembaga Pendidikan Ma'arif (LP Ma'arif). Pada bidang pendidikan formal para ulama NU Lampung menangani madrasah-madrasah dari PAUD, TK/RA, MTs, MA hingga Perguruan Tinggi. ${ }^{31}$ Sedangkan penyelenggaraan pendidikan non formal di lingkungan warga NU, dikoordinasikan oleh Rabithah al-Ma'ahid al-Islamiyah alNahdlyah (RMI) yang merupakan organisasi Ikatan Pondok Pesantran di lingkungan NU. Tujuan pendirian Pesantren adalah : (1) Pusat atau sentra pendalaman dan pengembangan ilmu-ilmu agama Islam; (2) Pusat kaderisasi ulama; (3) Pusat dakwah Islamiyah; (4) Pusat pengembangan dan pemberdayaan masyarakat Ciri Khas pendidikan di pesantren antara lain : (1) Kiai sebagai figure sekaligus teladan sentral para santri dan masyarakat; (2) Proses belajar full time 24 jam; (3) Santri tinggal di asrama selama 24 jam; (4) Terjadi ineraksi edukasisosial yang intensif antara santri - kiai. ${ }^{32}$

b. Melalui majelis-majelis Thariqah yang sasaran utamanya adalah kelompok orang dewasa/tua. Majelis-majelis atau aliran thariqah di Provinsi Lampung, menyebar di berbagai kabupaten/kota dengan nama atau aliran yang berbeda beda dan jumlah pengikut yang beragama pula. Namun paling tidak ada dua Pesantren yang jumlah jama'ah thariqahnya mencapai 25.000 an, yaitu Pondok Pesantren Nurus Sa'adah Brajadewa Way Jepara pimpinan KH Ahmad Shodiq dan Pondok Pesantren Padangratu pimpinan KH Jamaluddin Al-Bustomi.

c. Melalui tabligh / ceramah, khutbah dan dakwah secara umum kepada seluruh lapisan masyarakat tanpa membedakan usia yang dilakukan oleh kiai, ustad atau tokoh agama NU baik yang

\footnotetext{
${ }^{31}$ Marno TH., Wawancara Pribadi, 10 Agustus 2017

${ }^{32}$ Ihya Ulumuddin, Wawancara Pribadi, 11 Agustus 2017
} 
dikelola oleh PW NU melalui Lembaga Dakwah NU (LDNU) maupun secara mandiri oleh warga nahdliyin. Tak terhingga banyaknya penceramah kondang di Lampung ini yang berbasis NU dan gigih menyebarkan paham Ahlussunnah Wal Jama'ah.

d. Melalui jalur politik yang dilakukan oleh para politisi NU, baik yang berada di berbagai partai seperti Golkar, PDI, Gerindra dan lain sebagainya karena tokoh NU memiliki filosofi "tidak kemana-mana, tapi ada di mana-mana”. Namun demikian NU memiliki ikatan batin dan ikatan historis yang sangat kuat dengan 2 (dua) partai, PKB dan PPP. Sasaran utama dakwah melalui jalur politik ini adalah para elit politik, birokrat dan para pelaku usaha yang termasuk kaum menengah ke atas. Tujuannya adalah untuk mempengaruhi para elit politik, "decician maker", stake holders dan kelompok strategis lainnya agar paham keagamaan yang moderat Ahlussunnah Wal Jama'ah benar-benar membumi di masyarakat.

e. Melalui jalur lintas agama. Jalur ini ditempuh karena realitas masyrakat Indonesia, termasuk masyarakat Lampung sangatlah heterogen dan plural, baik dalam masalah agama yang dianut, etnis, adat-istiadat, budaya dan lain sebagainya. Persatuan, kesatuan dan kerukunan lintas agama menjadi sesuatu yang niscaya dan merupakan pilar kerukunan nasional. Untuk kelompok sasaran lintas agama ini, beberapa tokoh NU telah membentuk organ teknis berupa Lembaga Swadaya Masyarakat (LSM) yang khusus bergerak di bidang kelintas agamaan dengan nama Forum Kerja Lintas Agama (FKLA) sejak tahun 2004. Setelah keluarnya Peraturan Bersama antara Menteri Agama dan Menteri Dalam Negeri Nomor 9 dan Nomor 8 Tahun 2006 yang di antaranya mengatur tentang pembentukan Forum Kerukunan Umat Beragama, banyak tokoh dan pengurus NU yang aktif di kepengurusan FKUB, baik di tingkat Provinsi maupun Kabupaten.

\section{Penutup}

Sebagai organisasi keagamaan Islam, Nahdlatul Ulama Lampung mendasarkan paham keagamaannya pada al-Qur'an, Sunah, Ijmak dan Qiyas dengan menggunakan pendekatan bermazhab. 
Dalam kehidupan bermasyarakat, berbagsa dan beregara, NU menumbuh-kembangkan sikap tawasuth (moderta), tasamuh (tolerans) dan tawazun (harmoni) serta selalu menegakkan amar ma'ruf nahi munkar. NU juga memandang pluralitas berdasarkan prinsip-prinsip universal keadilan, kebersamaan dan kejujuran. Selanjutnya NU meletakkan konsep tata-kelola hubungan antar manusia dengan tiga bentuk ukhuwah yaitu: (1) ukhuwah islamiyah; (2) ukhuwah wathaniyah dan (3) ukhuwah basyariyah.

NU Lampung berupaya menyiarkan paham keagamaan yang moderat melalui jalur pendidikan baik formal maupun non formal, majelis-majelis thariqah, tabligh/ceramah, khutbah dan dakwah secara umum kepada seluruh lapisan masyarakat, jalur politik, dan melalui jalur lintas agama karena realitas masyarakat Indonesia, termasuk masyarakat Lampung sangatlah heterogen dalam masalah agama yang dianut. Banyak tokoh dan pengurus NU yang aktif di kepengurusan FKUB, baik di tingkat Provinsi maupun Kabupaten.

Ulama Nahdlatul Ulama memiliki peran yang sangat signifikan dalam menyebarkan paham keagamaan yang moderat di tengah masyarakat Lampung, sebab Ulama atau Kyai di lingkungan NU memiliki gaya dan cirri khas kepemimpinan kyai sebagai figur sentral yang selalu menjadi rujukan masyarakat dan bahkan menjadi sub kultur masyarakat Ulama atau Kyai seringkali ditempatkan sebagai pemimpin tunggal yang mempunyai kelebihan (maziyah) dan berkharisma, yang tidak dimiliki oleh unsur masyarakat lainnya. Kepemimpinan kyai yang demikian itu tanpa melalui pembinaan dan pemberdayaan yang baku, melainkan berproses secara alamiah. [] 


\section{DAFTAR PUSTAKA}

Al-Munawar, Said Agil Husin, Fikih Hubungan Antar Agama, Cet. Ke-3, Jakarta: Ciputat Press, 2005

Al-Shan'ani, Muhammad bin Isma'il, Subul al-Salam, Juz I, Bandung: Dahlan, tt.

Al-Suyuthi, Jalal al-Din Abd al-Rahaman, Al-Jami' al-Shaghir, Juz I, Indonesia: Dar Ihya' al-Kutub al-'Arabiyah, tt.

Al-Syathibi, Abu Ishaq, al-Muwafaqat, II, Mesir: Mushthafa al-Babi al-Halabi, 1976

Al-Zuhaili, Muhammad, Moderat dalam Islam, Cet. Ke-1, Jakarta: Akbar Media Sarana, 2005

Al-Zuhaili, Muhammad, Moderat dalam Islam, Cet. Ke-1, Jakarta : Akbar Media Sarana, 2005

BPS Provinsi Lampung, Provinsi Lampung dalam Angka 2017, Bandar Lampung, Cv. Jaya Wijaya, 2017

Fierlard, Andree, NU Vis A Vis Negara: Pencarian Isi, Bentuk, dan Makna, Yogyakarta: LkiS, 1992

Haedari, HM. Amin, Masa Depan Pesantren, Jakarta : IRD Press, 2004

Harahap, Ahmad Rifa'i dkk (ed), Ensiklopedi Praktis Kerukunan Umat Beragama, Cet. Ke-2, Medan: Perdana Publishing, 2015

Hasan, Muhammad Tholhah, Ahlussunnah Wal-Jama'ah dalam Persepsi dan Tradisi NU, cet. ke-3, Jakarta : Lantabora Press, 2005

Kantor Wilayah Departemen Pendidikan dan Kebudayaan Propinsi Lampung, Sejarah Daerah Lampung, Bandar Lampung: Bagian Proyek Pengkajian dan Pembinaan Nilai-Nilai Budaya Lampung, 1997

Karim, M. Rusli, Negara dan Peminggiran Islam Politik, Yogyakarta: Tiara Wacana, 1992

Mujanni, Saiful, Kultur Kelas Menengah Muslim dan Kelahiran ICMI: Tanggapan terhadap Robert $W$ Hefener dan Mitsuo Nakamura, dalam Nasrulloh Ali Fauzid (Ed), ICMI : Antara Status Quo dan Demokrasi, Bandung: Mizan, 1995 
Mulkhan, Abdul Munir, Perubahan Perilaku dan Polarisasi Ummat Islam 1965-1987, Jakarta: Rajawali Press, 1989

Panjang, Hasymi DT. R., Pembelajaran Al-Qur'an dan Hadis, Padang: Haysa Press, 2012

Pranowo, Bambang, Islam Faktual: Antara Tradisi dan Relasi Kuasa, Yogyakarta: Adicita Karya Nusa, 1999

PWNU Propinsi Lampung, Sepintas Sejarah NU Lampung, Lampung, 2014

Rachman, Budhy Munawar, Argumen Islam untuk Pluralisme, Jakarta: Grasindo, 2010

Raharjo, M. Dawwam, Visi dan Misi Kehadiran ICMI: Sebuah Pengantar, dalam Nasrulloh Ali-Fauzid (Ed), ICMI: Antara Status Quo dan Demokrasi, Bandung: Mizan, 1995

Rumadi, Andi Najmi Fuaidi, Mahbub Ma'afi (ed), Hasil-Hasil Muktamar Ke-33 Nahdlatul Ulama, Cet. Ke-1, Jakata : Lajnah Ta'lif wan Nasyr PBNU, 2015

\section{Makalah Ilmiah dan Artikel}

Mahfudh, Sahal, Pidato Iftitah Rais 'Aam PBNU pada acara Musyawarah Nasional/Komferensi Besar NU, Jakarta, tanggal 25 Juli 2002

Tim Penyusun Kementerian Agama Provinsi Lampung, Kementerian Agama Provinsi Lampung dalam Angka: Data Statistik Keagamaan Tahun 2014, (Bandar Lampung, Kementerian Agama Provinsi Lampung, 2015

\section{Wawancara}

Khairuddin Tahmid, Wawancara Pribadi, 12 Agustus 2017.

Marno TH., Wawancara Pribadi, 10 Agustus 2017

Ihya Ulumuddin, Wawancara Pribadi, 11 Agustus 2017 